\title{
Putting God on the Map: Theology and Conceptual Mapping
}

Kidd, Erin and Jakob Karl Rinderknecht, eds. Putting God on the Map: Theology and Conceptual Mapping. Lanham, MD: Lexington Books/Fortress Academic, 2018. 268 pp. \$105.00. Hardback. ISBN: 9781978703964.

Putting God on the Map: Theology and Conceptual Mapping, edited by Erin Kidd and Jakob Karl Rinderknecht, is a collection of essays that applies insights from cognitive linguistics to theological inquiry. Readers might wonder why cognitive linguistics fits with theology. The answer is that cognitive linguists have discovered that language, and therefore the way people think, is structured by metaphors which are themselves grounded in physical experience of the world. As Robert Masson puts it in the forward, "research in cognitive linguistics upends the conventional notion that literal meaning is foundational" (xii). If this is true, what are the implications for theology? What new opportunities are afforded to God-talk when one places metaphor and non-literal meaning at the center of our language and thinking?

The introduction to the volume by Kidd and Rinderknecht contextualizes the essays that follow by providing a brief overview of cognitive linguistics, including a discussion of pioneers in the field and definitions of key terms used throughout the volume. They then briefly review two theological monographs that draw on cognitive linguistics: Masson's Without Metaphor, No Saving God: Theology after Cognitive Linguistics (Studies in Philosophical Theology, Walpole, MA: Peeters, 2014) and John Sanders's Theology in the Flesh: How Embodiment and Culture Shape the Way We Think about Morality, Truth, and God (Minneapolis: Fortress Press, 2016). The introduction is rounded out with a summary of the essays in the book.

The first two essays in the volume address the possibility of theological language in light of cognitive linguistics. Kidd argues that bodies shape thinking and thinking shapes perception of the world. This does not undermine theological discourse, but it is rather the very condition of theology. Kidd's essay is particularly important because George Lakoff and Mark Johnson have argued in Philosophy in the Flesh: The Embodied Mind and its Challenge to Western Thought (New York: Basic Books, 1999) that our embodied condition excludes the possibility of thinking and speaking of the transcendent. Next, Julia Feder argues against a limiting dualism between the symbolic world and the material world in the work of evolutionary anthropologists. She uses insights from cognitive linguistics, paired with Edward Schillebeeckx's notion of sacrament, to dissolve that dualism. She argues, "The symbolic is not behind or beneath the material, but rather it is expressed in and through the material" (53).

Cognitive linguistics is brought to bear on scripture in the next two essays. Jason P. Roberts uses "conceptual integration theory" (CTI), developed by Giles Fauconnier and Mark Turner, to understand human distinctiveness. CTI informs Roberts's exegesis of "image of God” passages in Genesis. This allows him to articulate human uniqueness without drawing an ontological divide between humans and the rest of the animal kingdom. Christopher M. Hadley also provides an exegetical discussion informed by cognitive linguistics. Hadley shows that problems associated with Paul's use of the term "kenosis" are solved by a theory of language development called "double-scope blending." Double-scope blending takes concepts from two distinct sources and maps them onto a 
single new source, thereby creating new knowledge. Hadley demonstrates how Paul draws imagery from distinct sources and blends them together in Philippians 2:5-11 and 3:7-16. He then applies his conclusions to a discussion of Hans Urs von Balthasar's theology.

The next few essays demonstrate the fruitfulness of cognitive linguistics for intra-religious dialogue. Stephen R. Shaver uses "metaphoric asymmetry" to make sense of two major approaches to the Eucharist. He identifies these approaches as liturgical ("Bread is Jesus") and ecumenical ("Jesus is bread"). Metaphoric asymmetry allows Shaver to carefully analyze what is distinct as well as what is common between these two traditions. Similarly, Rinderknecht argues that "conceptual mapping demonstrates far-reaching potential” for Christian ecumenism (180). Rinderknecht suggests that different Christian groups disagree not because they misunderstand the words used by the other group but "because their language is predicated on different [conceptual] blends" (163). He examines a US Lutheran-Roman Catholic dialogue called The Eucharistic Sacrifice as an example of how conceptual maps shape the meaning of key terms for ecumenical dialogue.

The volume concludes with two essays on theological ethics. Adam Willows addresses a theoretical question about altruism: is it possible to be altruistic if the agent benefits from the action in question? Willows finds in Aquinas a mapping of the concept of "the good" onto the concept of "God" such that "love of self" and "love of the other" are both instances of "love of God" (202). Therefore, according to Willows, whether one seeks one's own good or the good of others, it amounts to the same: seeking God. Kathryn Lila Cox moves from the theoretical to the practical in a discussion about frozen embryos from the perspective of Catholic ethicists. The Congregation for the Doctrine of Faith's Dignitas Personae states that unused and abandoned frozen embryos are "a situation of injustice which in fact cannot be resolved" (quoted on 214). Cox does not offer a solution to this quandary, but she does analyze how "conceptual blending” both reveals and conceals our assumptions about what exactly we believe frozen embryos to be.

There is not space in this review to consider the merits of each individual essay, so I will offer my comments on the value of the collection as a whole. The strength of Putting God on the Map is its unique contribution to the field of theology. To my knowledge, there is not yet a developed body of theological scholarship that draws so heavily on cognitive linguistics. Notable exceptions are Masson's Without Metaphor, No Saving God and Sanders's Theology in the Flesh, both mentioned in this volume. The challenges posed by cognitive linguistics to traditional epistemology and metaphysics are significant. Insofar as mainstream theological discourse is indebted to traditional epistemology and metaphysics, it is necessary that those who value God-talk take these challenges seriously. The editors and contributors to this volume have done just that. In addition to being a pioneering work, this volume is a superb model of interdisciplinary research. Each contributor has carefully engaged with scholarship from cognitive linguistics. Each has also identified important questions in theological research. The use of insights from one discipline to address the questions of another discipline is, in my opinion, the hallmark of useful interdisciplinary research.

Taken as a whole, these essays are also valuable because they address a significant range of subdisciplines within theology. Any reader will come away from these essays with a clear understanding of how cognitive linguistics may illuminate a whole host of theological topics. Furthermore, many of the essays provide useful diagrams to illustrate complicated concepts such as "Conceptual Integration" (figure 4.1) and "Double-Scope Blends" (figure 7.2). There are 23 such diagrams throughout these essays each of which aids the reader in understanding the authors' arguments. 
Finally, each essay contains its own introduction to concepts from cognitive linguistics. When this is paired with the introductory essay, some readers may find this redundant. However, one reading the entire collection will read several different approaches to cognitive linguistics. This allows for a diversity of approaches and reinforces the concepts learned. If, by contrast, one only reads one of these essays and forgoes the introduction, the reader will still come away with a preliminary understanding of cognitive linguistics.

While specialists in either theology or cognitive linguistics may find details to quibble with in this volume, I find no major shortcoming in the material presented as a whole. That said, I believe there is a missed opportunity here: an essay addressing interreligious dialogue with the tools provided by cognitive linguistics. Admittedly, it may be unfair to criticize a work for not including something it did not claim to include. However, Masson (who was not an editor) notes in his forward that the tools provided by cognitive linguistics are useful for "charting our fractured religious landscape" (xi). Yet these essays are limited to Protestant and Catholic perspectives. The volume would have been greatly strengthened by also including essays addressing issues in other religious traditions as well as dialogue between those traditions. I hope that some scholar or group of scholars takes this interdisciplinary research in that direction.

One does not have to accept the premises nor agree to the conclusions of these essays to appreciate their contributions to a wide variety of theological questions. Any theological library or collection will be enhanced by this volume. There are two types of patrons who will find these essays useful. The first, and perhaps most obvious, is the patron who wants to learn something about cognitive linguistics. Although each essay engages in different theological subdisciplines, the obvious common theme is the application of "conceptual mapping." Reading conceptual mapping briefly explained and then applied by several different scholars serves as a wonderful introduction to the topic. The second type of patron who may be interested in this volume is the one whose primary interest is with a specific theological topic covered in this volume. For example, the ethicist interested in reproductive issues may find Cox's article a fresh and informative take on a well-known topic. Indeed, it is the interdisciplinary aspect of this volume that is its greatest contribution.

Micah Saxton Research Librarian for the Humanities Tufts University Medford, MA 